\title{
The Strength of the Fragrance for One and a Half Thousand Years: Agarwood in the Japanese Art of Incense
}

\author{
E. E. Voytishek, A. A. Rechkalova
}

Novosibirsk State University

Novosibirsk, Russian Federation

Abstract

This article gives a brief overview of the genesis of the development of incense culture in Japan through the determining function of aromatic wood in Buddhism, as well as the significance of Japanese classifications of agarwood (aquilaria) species which were developed in the $16^{\text {th }}-17^{\text {th }}$ centuries. Japanese masters invented ways of coding fragrances of aromatic wood through their characteristics of tastes and place of growth, as well as using metaphorical and figurative-symbolic meaning of each name. These techniques played a key role in the history of the traditional art of koudou ('way of fragrance') and in the development of female education during the Edo period (1603-1867). Based on the analysis of written sources and museum collections, two classifications were studied, which are still used in Japan when assessing the quality of aromatic wood and wood products: a list of ' 61 kinds of aromatic wood', developed using associations of odours with significant phenomena in Japanese society as its foundation - calendar holidays, religious concepts, political and literary characters, as well as the system of 'Six Countries - Five Flavours', which was based on geographical factors and the principle of reliance on taste and olfactory receptors.

Keywords

agarwood, aquilaria, Japan, Awaji island, classification of aromatic wood, koudou incense art ("the way of fragrance"), Buddhism

Acknowledgements

The authors would like to express their deepest gratitude to Honourary Professor of Kyoto University Mr. Kobayashi Tooru (古林徹) and his wife Kobayashi Taeko (古林妙子) for the rare opportunity to visit the famous shrines on Awaji island during the hot summer of 2018. A heartfelt thank you to the brilliant translator and Japanese literature expert T. L. Sokolova-Delusina for her kind permission to collaborate on the translation of the medieval texts mentioned in this work.

For citation

Voytishek E. E., Rechkalova A. A. The Strength of the Fragrance for One and a Half Thousand Years: Agarwood in the Japanese Art of Incense. Vestnik NSU. Series: History and Philology, 2020, vol. 19, no. 10: Oriental Studies, p. 117-129. DOI 10.25205/1818-7919-2020-19-10-117-129

\section{Сила аромата в полторы тысячи лет: \\ агаровая древесина в японском искусстве благовоний}

\section{Е. Э. Войтишек, А. А. Речкалова}

Новосибирский государственный университет

Новосибирск, Россия

Аннотация

Данная статья посвящена изучению японских классификаций пород ароматической древесины агарового дерева (аквилярии), которые были разработаны в XVI-XVII вв. Поскольку предпосылки создания этих классификаций и их структурные особенности тесно связаны с историей развития ароматической культуры на Япон- 
ском архипелаге, сначала дан краткий экскурс в историю вопроса. На основе данных исторических хроник, средневековых литературных и художественных произведений, делопроизводственной документации религиозных институтов был проведен анализ формирования методик оценивания ароматических компонентов и их производных, а также рассмотрены сферы их применения. Средневековые японские мастера искусства 香道 ко:до: («путь аромата») создали уникальные техники кодирования видов ароматической древесины. В данной работе подробно рассмотрены две основные классификации, которые до сих пор используются в Японии при оценивании качества древесины и изделий из нее: перечень из «61-го вида ароматической древесины», разработанный на основе ассоциаций запахов со значимыми феноменами в жизни японского общества - календарными праздниками, религиозными понятиями, политическими деятелями и литературными персонажами, а также система «шесть стран - пять вкусов», в основе которой лежали географические факторы и принцип опоры на физиологические - вкусовые и обонятельные - рецепторы. Будучи частью узкопрофессионального знания мастеров искусства ко:до:, эти системы и классификации перешагнули экономические, социальные и гендерные барьеры, став одним из показателей социализации и уровня образованности для самых широких слоев населения. Это прослеживается, в частности, на материале учебных пособий для женщин, которые издавались в конце XVIII в. Соединившись с идейно-мировоззренческой основой буддизма и взяв на вооружение принципы аристократической, а позднее и самурайской культуры, использование благовоний через разнообразные методики, приемы и аксессуары со временем трансформировалось не только в традиционное искусство, но и в определенный символ национальной культуры, во многом основанный на осознании ценности текущего момента и быстротечности жизни.

Ключевые слова

агаровое дерево, аквилярия, Япония, остров Авадзи, классификации ароматической древесины, искусство ко:до: («путь аромата»), буддизм

Благодарности

Большая благодарность почетному профессору университета Киото господину Кобаяси Тоору (古林徹) и его супруге Кобаяси Таэко (古林妙子) за редкую возможность посещения знаменитых святилищ на острове Авадзи в жаркое лето 2018 г. Сердечная признательность блестящему переводчику и эксперту в японской литературе Т. Л. Соколовой-Делюсиной за любезное согласие сотрудничать в переводе упоминающихся в работе средневековых текстов.

Для ичитирования

Войтишек Е. Э., Речкалова А. А. Сила аромата в полторы тысячи лет: агаровая древесина в японском искусстве благовоний // Вестник НГУ. Серия: История, филология. 2020. Т. 19, № 10: Востоковедение. С. 117-129. (на англ. яз.) DOI 10.25205/1818-7919-2020-19-10-117-129

\section{Introduction}

The emergence of aromatic raw materials of plant and animal origin in Japan is associated with the penetration of a whole complex of ideological, religious and cultural borrowings from China, Korea and the southern tropics in the $6^{\text {th }}-7^{\text {th }}$ centuries, which, in turn, was a result of the formation and development of trade and economic ties in the region. In addition to various parts of plants flowers, fruits, roots, leaves, resin used as aromatic substances, the incense of animal origin (ambergris, musk, civetin, etc.), as well as minerals, shellfish, and others were widely used in Japan.

However, among the aromatic substances, wood, even today rightfully occupies the most honourable place. Since ancient times, various types of wood of aromatic trees has been highly valued in Japan, many varieties of which grow in the tropical zone of Southeast and South Asia. Just like in Asia, wood of the agar tree (Japanese 沈香 jinkou, or 沈水香木 jinsui-kouboku, meaning 'the fragrance sinking [in water] / aromatic tree') ${ }^{1}$, has always held the highest status in Japan, which remains to this day. The finest types of this aromatic wood exude the exquisite scent of 伽羅 kyara (in Sanskrit 'black agar wood', 'fragrance'). Over time, an entire system of combining various types of aromatic components was developed, and criteria for evaluating the merits and scope of a particular aroma were formed. The ability to give various types of fragrances exquisite names with deep ideological, philosophical and literary connotation was an especially valued skill, which was also

\footnotetext{
${ }^{1}$ The wood of the agar tree, or aquilaria (latin Aquilaria agallocha Roxb.), sinking in water due to the abundance of resin, has many names in different languages: 'aloe agalloch tree', 'eagle tree', 'oud tree', 'aloe', 'Kalambak', 'heavenly tree', 'blind tree', 'sinking tree', etc.
} 
reflected in a large number of classifications of fragrant wood and corresponding fragrances in the history of Japanese culture.

\section{The origins of the use of aromatic aquilaria wood}

According to the 'Chronicle of Japan' (日本書紀 Nihon shoki, 720), the use of aromatic wood in the Japanese archipelago began during the era of Empress Suiko (554-628), when a whole piece of agarwood (aquilaria) was washed ashore on the island of Awaji ${ }^{2}$, which, due to its unusual qualities, was then sent to the imperial court [Nihon shoki, 1997. Vol. 2. P. 91]. There are also written records attesting the fact that Prince Shotoku Taishi (聖徳太子, 574-622) respectfully accepted the gift of the coastal inhabitants of Awaji island, while Empress Suiko in the 3rd year of her reign (595) ordered a Korean master from Baekje to carve a statue of the Kannon Bodhisattva out of this wood, which was later assigned to the Hisodera Temple in Yoshino (吉野比蘇寺). For example, this famous episode of the efforts of the Japanese court to strengthen Buddhism is mentioned in the book 'Biography of Shotoku Taishi' (聖徳太子伝糜 Shotoku Taishi denryaku) ${ }^{3}$. Based on this chronicle, a series of paintings 'Illustrated Biography of Shotoku Taishi' was created in 1069, which were originally placed on the door panels of one of the pavilions of the Horyuji Temple (Fig. 1) ${ }^{4}$.

The fate of the historical piece of aromatic aquilaria wood, found off the coast of Awaji island in 595 is also noteworthy; sources claim that during the Asuka period, it appeared in the capital's Horyuji Temple (法隆寺), founded in the early VII century by Prince Shotoku Taishi. Since then, the history of the ancient Horyuji Temple is inextricably linked with the history of the development of aromatic plants and trees in Japanese culture, and the study of the properties and functions of aromas in religious and everyday life spheres [Ota Kiyoshi, 2001. P. 30-31]. Like so, an entry in the consolidated register of documents 'Description of the history and property of the Horyuji Temple' (法隆寺伽藍縁起并流記資財帳 Houryuji garanengi narabini ryuuki shizai chou) ${ }^{5}$ has been preserved that testifies to the active trade and economic activities of the temple and its ceremonial needs.

Along with Horyuji, another temple in Nara played an outstanding role in spreading the tradition of using incense, namely the Buddhist Todaiji Temple (東大寺) ${ }^{6}$. In the national treasury Shoso-in (正倉院), a fragment of aquilaria wood (the best variety with the kyara scent) has been kept on its territory for a long time, which has two names - 黄熟香 oujuku-kou ('ripe yellow aroma') and 蘭奢

\footnotetext{
${ }^{2}$ On the territory of the Izanagi Jingu sanctuary in October 1995, two stone steles were erected to commemorate the event of almost fifteen hundred years, one of which depicts the hieroglyph 香 ('fragrance'), and the other contains a fragment of text from the $22^{\text {nd }}$ scroll of the chronicle. The sanctuary of Kareki Jinja ('Temple of the Dry Tree'), where a piece of beached aquilaria wood was found, brought by a wave, is located nearby on the coast (materials of E. E. Voytishek's trip to Awaji in July 2018).

${ }^{3}$ The historical record, also known as 'Biography of Taishi' (太子伝 Taishi den) was compiled by poet Fujiwara-no Kanesuke (藤原兼輔, 877-933) approximately in 917, based on the earlier work of a monk from the Kudaraji Temple (百 済寺). URL: Shotoku Taishi denryaku [聖徳太子伝暦]. Description of the Biography of Shotoku Taishi. 2 scrolls. Scroll 2 in 2 parts. Part 2 // Online Collection of the National Parliamentary Library. URL: https://dl.ndl.go.jp/info: ndljp/pid/2544997?tocOpened=1 (accessed 01.07.2020).

4 'Arrival of the sacred tree' fragment (霊木漂着) illustrated on Panel № 4 (1305 copy). Tokyo National Museum. Shotoku Taishi e-den [聖徳太子絵伝]. Illustrated Biography of Prince Shotoku (1305) // Online Cultural Heritage Website. URL: https://bunka.nii.ac.jp/heritages/detail/147157/2 (accessed 07.07.2020).

${ }^{5}$ The document is also known as the 'Financial Book of Horyuji' (法隆寺資財帳 Houryuuji shinzaichou), the initial compilation of which dates back to 747. The original has not survived to this day. See: Ishigami Eiichi. Houryuuji garanengi narabini ryuuki shizai chou shoshahon-no denrai [法隆寺伽藍縁起并流記資財帳諸写本の伝来]. Introduction of the handwritten document 'Descriptions of the history and property of the Horyuji Temple' // Journal of the Institute of Historiography of Tokyo University. Tokyo: Toukyou daigaku shiryou hensanjo, 1976, № 10. P. 1-10.

${ }^{6}$ Together with Horyuji Temple, it is one of the seven largest southern temples (南部七大寺).
} 
待 ranjatai ('to receive an exceptional long-awaited aroma'). With the characters of ranjatai, it is customary to include the concealed characters of the name of the Buddhist Todaiji Temple.
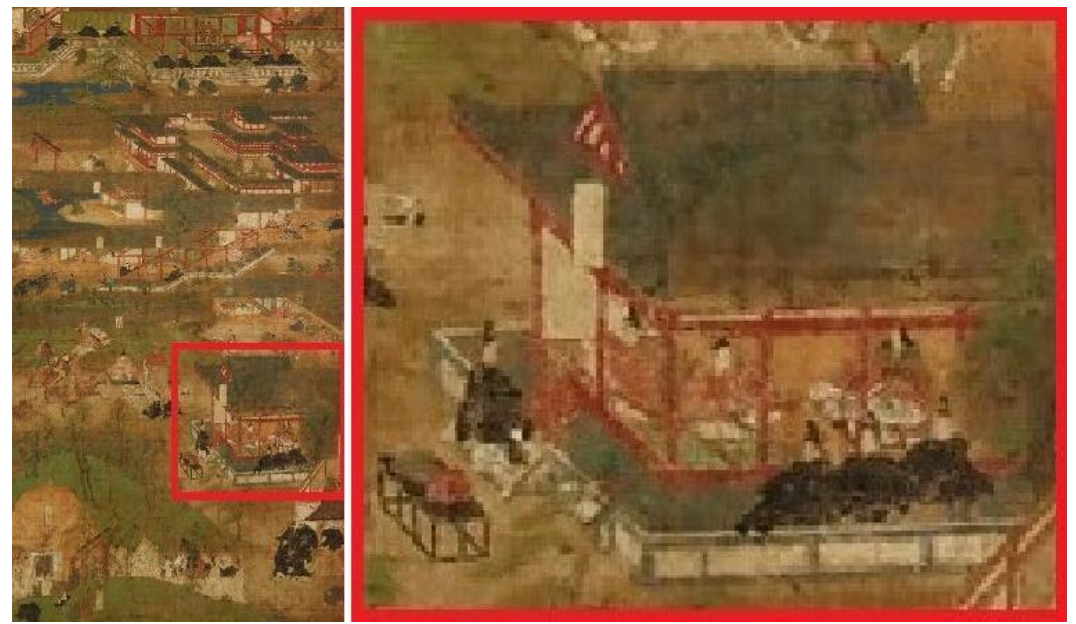

Fig. 1. Panel № 4 'Illustrated Biography of Prince Shotoku', 'arrival of the sacred tree' fragment 1305 copy, Tokyo National Museum. Shotoku Taishi e-den [聖徳太子絵伝]. Illustrated Biography of Prince Shotoku (1305) // Online Cultural Heritage Website. URL: https://bunka.nii.ac.jp/ heritages/detail/147157/2 (accessed 07.07.2020)

Рuc. 1. Панель № 4 «Иллюстрированная биография принца Сётоку». Фрагмент «Прибытие священного дерева», копия 1305 г., Национальный музей Токио

A piece of ranjatai wood (156 cm long, $11.6 \mathrm{~kg}$ in weight, measuring $42.5 \mathrm{~cm}$ at its widest part) is recognized as an important national treasure. It continues to have a high reputation, embodying in a certain sense the imperial power [Shoso-in, 1994. P. 40]. There are many extraordinary stories associated with this piece of wood. According to legend, it was transported from China to Empress Komyo in 756 to the Todaiji Temple. As a result, it ended up with other treasures of Emperor Shomu in the special Shoso-in storehouse to perpetuate his memory and is kept there to this day [Peace and Harmony, 2011. P. 112].

As for the initial uses of aromatic raw materials, at the beginning of the Nara era (710-784), along with the spread and consolidation of Buddhism, a large amount of aromatic wood was brought from mainland China to Japan. At that time, it was widely used in Buddhist memorial services (it was burned in front of a sign with the name of the deceased). Since this kind of wood was not known to contain wood bugs, it was also used to manufacture cases for storing sutra scrolls and writing brushes. In addition, this wood was also often used to make jewellery boxes, game boards, handles and sword sheaths ${ }^{7}$.

Since the Heian era (794-1185), pieces of aromatic wood burning on a Buddhist altar were called 名香 myougou ('aromatic trees with a fine smell'), and this term was assigned the meaning of 'a scent presented as a gift to Buddha'. During the Muromachi period (1336-1573), the pronunciation of this word changed - it began to sound similar to meikou (short for 名物の香 meibutsu-no kou - 'the aroma of fine items'). This name acquired the following meanings - 'aroma of noble

\footnotetext{
${ }^{7}$ Tokyo National Museum Website. Exhibition of $7^{\text {th }}$ century treasures from the Buddhist Horyuji Temple in Nara (April-September 2020). URL: https://www.tnm.jp/modules/r_exhibition/index.php?controller=item\&id=3049 (accessed 07.05.2020).
} 
origin’ (由緒ある香 yuisho aru kou), 'aroma of a wonderful fragrance' (香気の優れた香 kouki-no sugureta kou), for wood included ${ }^{8}$.

\section{Aromatic aquilaria wood classifications in Japan}

Specifically the Muromachi period can be credited for the beginning of classifications of 名香 meikou high-quality fragrant wood in Japan, which subsequently gained great fame.

Among the most famous is the classification of 180 types of fragrant wood, developed by military leader of the period of the Southern and Northern courts who was famous for his extravagance, Sasaki Doyo (佐々木道誉, 1296-1373), as well as the classification of ten types of fragrant wood, compiled by tea master Yamanoue Soji (山上宗二, 1544-1590). There were other lists of fragrant wood, including 66 types (六十六種名香), 120 types (百二十種名香), 130 types (百三十種名香) and even 200 types (二百種名香) [Jinbo Hiroyuki, 2003. P. 446].

By order of the 8th shogun of the Muromachi period, Ashikaga Yoshimasa (足利義政, 14361490), a famous patron of the arts, the head of the main schools of the 'aroma path' 香道 koudou Shino Soushin (志野宗信, 1443-1522), founder of the Shino-ryuu school (志野流), and Sanjonishi Sanetaka (三条西実隆, 1455-1537), founder of the Oie-ryuu school (御家流), were given the task of compiling a list of the best wood aromas, taking into account the specifics of the scent and place of growth, resulting in the ' 61 kinds of aromatic wood' list (六十一種名香 rokujuu isshu meikou), which to this day is still considered to be the set standard in Japanese fragrance art ${ }^{9}$.

It is worth mentioning that the list of 61 types of aromatic woods starts with two types of agar trees that have special names, named after the temples where the fragments of wood were originally located - 法隆寺 Horyuji (or 太子 Taishi) ${ }^{10}$ and 東大寺 Todaiji (or 蘭奢待 Ranjatai).

List of 61 types of aromatic wood

法隆寺・東大寺（蘭奢待）・覓遥・ 三芳野・紅塵・枯木・中川・法華経・花橘・八 橋・園城寺・似・不二の煙・菖蒲・般若・麃鴣斑・青梅・楊貴妃・飛梅・種島・澪標・

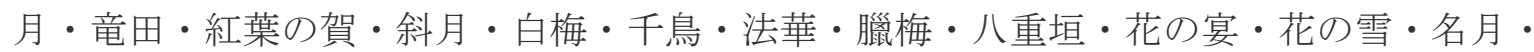

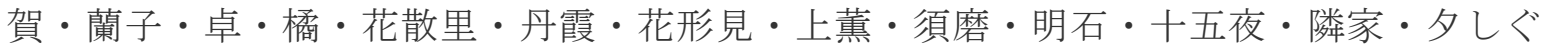
れ・手枕・有明・雲井・紅・泊瀬・寒梅・二葉・早梅・霜夜・七夕・寝覚・東雲・薄紅 $・$ 薄雲・上馬

Horyuji, Todaiji (Ranjiatai), Shoyo (Stroll), Miyoshino, Kojin (Red Dust), Dead Koboku Tree, River Nakagawa, Hokekyo (Lotus Sutra), Hana-tachibana (Blooming Citrus) ${ }^{11}$, Yatsuhashi (Eightpiece Bridge) ${ }^{12}$, Onjoji Temple ${ }^{13}$, Nitari (Similarity), Fuji-no kemuri (Smoke over Fuji), Ayame (Iris), Hannya (Prajna), Shakoban (Spots of Pearl of Black Francolin) ${ }^{14}$, Aoume (Green Plum),

\footnotetext{
${ }^{8}$ Traditions of using incense in Japan and the Japanese classifications of aromatic wood. URL: https://www. kigusuri.com/kampo/asano/asano_21.html (accessed 08.05.2020).

${ }_{9}^{9}$ According to some references, this normative list had to be memorized [Jinbo Hiroyuki, 2003. P. 446].

${ }^{10}$ The Horyuji Temple in Nara is strongly associated with the name of its founder, Prince Shotoku Taishi, who actively supported ties with China and the spread of Buddhist teachings.

${ }^{11}$ Can also be translated as tangerine, or Tachibana orange (a poem from the anthology of the $10^{\text {th }}$ century. 'Kokin Wakashu').

${ }^{12}$ The yatsuhashi bridges are an image from the lyrical narrative of the Heian era 'Ise monogatari' [Ise monogatari, 1979. P. 46].

${ }^{13}$ The Onjoji Temple, also known as Miidera, was founded in 672 by Emperor Tenmu (631-686) after the Jinshin Troubles, in which he overthrew the son of his late brother Emperor Tenji and took the throne. It is located at the foot of Mount Hiei, near Lake Biwa. From the end of the VI century, the temple was one of the four most influential Buddhist institutions, along with Todaiji, Kofukuji and Enraykuji. See: Omi meisho zue [近江名所図会]. Lists of attractions of the Omi Province (1797) // Online Collection of the International Institute for Digital Humanities. URL: http://www2.dhii.jp/ nijl_opendata/searchlist.php?md=thumbs\&bib=200017488 (accessed 07.07.2020).

${ }_{14}$ 'Pearl Francolin Marks' - the name indicates the spotted wood, similar to the plumage of the pearl francolin shako (quail).
} 
Yang Guifei, Tobiume ${ }^{15}$ (Flying Plum), Tane-ga shima, Miotsukushi ${ }^{16}$, Tsuki (Moon), Tatsuta ${ }^{17}$, Momiji-no ga ${ }^{18}$, Shagetsu (Moon Bowing to the West), Hakubai (White Plum), Chidori (Sandpiper), Hokke (Flower of the Law), Robai (Winter Blossom) ${ }^{19}$, Yaegaki (Eight-Layer Fence) ${ }^{20}$, Hana-no en ${ }^{21}$, Hana-no yuki (Flower Snow) ${ }^{22}$, Meigetsu (Full Moon), Ga (Celebration) ${ }^{23}$, Ransu (Orchid Child), Joku (Near the Altar) ${ }^{24}$, Tachibana (Citrus), Hana-chirusato ${ }^{25}$, Tanka (Red Clouds, pierced by sun rays), Hana-gatami (Flower Basket) ${ }^{26}$, Uwadaki (Fume for the Top Dress), Suma, Akashi ${ }^{27}$, Jugoya (Fifteenth Night), Rinka (House Next Door) ${ }^{28}$, Yushigure (Evening Rain), Tamakura (Hand pillow), Ariake (Pre-Dawn Moon), Kumoi (Cloud Abode), Kurenai (Scarlet), Hatsuse, Kanbai (Winter Plum), Futaba (Two First Leaves), Sobai (Early Plum), Shimoyo (Cold Night) ${ }^{29}$, Tanabata (Seventh Night), Nezame (Awakening), Shinonome (Dawn Clouds), Usukurenai (Pink) ${ }^{30}$, Usukumo ${ }^{31}$, Noboriuma (Beautiful Horse) ${ }^{32}$.

It must be mentioned that all these types of aromas belong to different varieties of agar wood 沈 香 jinkou, the features of which differ significantly from each other depending on the place of growth and the type of forming. This list was compiled taking into account the specifics of different types of agar wood.

In terms of the features of this list, in addition to the first names associated with the main and oldest Buddhist temples of Nara, the rest of the names are mostly the names of seasonal phenomena, ceremonies and observances of the Chinese calendar (for example, the autumn festival of the clear moon 十五夜 jugoya ('Fifteenth Night'), the celebration of Bootes and Weaver 七夕 tanabata and others). In addition, a number of agar wood varieties are named in association with poetic and figurative names of plants and trees ('Early Plum' 早梅 sobai; 'Green Plum' 青梅 aoume ${ }^{33}$; 'Winter Plum' blooming in the cold 寒梅 kanbai and others) as well as established traditional culture images (bridge with eight sections 八橋 yatsuhashi ${ }^{34}$ in a Japanese garden; a special 'seasonal word' in Japanese poetry 夕時雨 yushigure ‘Evening Rain', associated with winter, and others).

${ }^{15}$ The concept is associated with Sugawara Michizane (845-903), who in 901 was accused of court intrigue and exiled to Kyushu Island. Going there, he mourned the separation from the pine, sakura and plum trees growing in his garden. According to legend, when he left the capital, the sakura withered from melancholy, and the plum and pine flew across the sky towards him at Kyushu. The pine tree exhausted itself on its way and, before reaching him, fell into the territory of Suma, where it took root, and the plum managed to fly to his new place of residence. The plum tree is now the symbol of Anrakuji Temple 安楽寺 in Dazaifu (Kyushu).

${ }^{16}$ Chapter 14 title ('At the buoys') from 'The Tale of Genji'; by Murasaki Shikibu.

${ }^{17}$ Tatsuta River - a famous place for admiring the scarlet autumn maples momiji.

${ }^{18}$ Chapter 7 title ('Celebration of the scarlet maples') from 'The Tale of Genji'; by Murasaki Shikibu.

${ }^{19}$ The early maturing Himonant - a tree with yellow flowers, from the plum species that blooms almost simultaneously with the plum.

${ }^{20}$ A concept from the $8^{\text {th }}$ century 'Kojiki' chronicles ('In Izumo, where clouds form into eight ridges, / Chamber in eight fences, / To cover up the wife...' [Kojiki, 1994. P. 60; Kojiki, 2014. P. 103-104].

${ }^{21}$ Chapter 8 title ('Celebration of flowers') from 'The Tale of Genji'; by Murasaki Shikibu.

${ }^{22}$ A poetic image based on the technique called 見立て mitate - likening plum flowers to snow.

${ }^{23}$ This festive scent was used on the $50^{\text {th }}$ anniversary of Ashikaga Yoshimitsu in 1408, that is, shortly before his death.

${ }^{24}$ A sacrificial table for incense in front of a Buddhist altar.

${ }^{25}$ Chapter 11 title ('The garden where the flowers fall') from 'The Tale of Genji'; by Murasaki Shikibu.

${ }^{26}$ The title of the play yokyoku for Noh Theatre, authored by famous playwright Zeami (1363-1443).

${ }^{27}$ The successive chapter titles from 'The Tale of Genji' by Murasaki Shikibu: Suma (Ch. 12) and Akashi (Ch. 13).

${ }^{28}$ According to legend, warlord Sasaki Doyo received this aromatic wood from a neighbour - hence the name.

${ }^{29}$ Literally - 'The night when the frost falls'.

${ }^{30}$ The image, potentially connected to a poem by Saigyo (1118-1190), the famous hermit poet of the late Heian era, who praised the soft pink sakura.

${ }^{31}$ Chapter 19 title ('Melting cloud') from 'The Tale of Genji'; by Murasaki Shikibu.

${ }^{32}$ Refers to the horse that was bred during Shinto rites.

${ }^{33}$ The name aoume refers to the type of agar wood, characterized by a sour-bitter aroma, characteristic of the taste of a green plum.

${ }^{34}$ This type of agar wood is characterized by its strong aroma with a bitter taste. 
A number of names do not refer to the original images of Japanese culture and literature, but instead refer to well-known Buddhist works (for example, the 'Lotus Sutra' 法華経 Hokekyo), widely used Buddhist concepts such as 般若 hannya ('wisdom', 'insight', Sanskrit: Prajñā) and 紅塵 kojin (literally 'Red Dust' meaning 'secular vanity'), or even famous characters such as the beautiful Yang Guifei 楊貴妃 - the beloved of the Chinese Emperor Xuan-zong (685-762).

However, most of the names of aromatic wood types in the list are associated with Japanese classical literature. Apart from references to well-known theatrical dramas (for example, Zeami's 'Flower Basket' play 花形見 Hanagatami), there are many examples from a famous work of the Heian period - 'The Tale of Genji', written at the turn of the $10^{\text {th }}-11^{\text {th }}$ centuries by Murasaki Shikibu. Generally, these are chapter titles from the famous work: 'Celebration of the Scarlet Leaves' 紅葉の賀 (Ch. 7); 'Celebration of Flowers'花の宴 (Ch. 8); 'Garden Where the Flowers Fall' 花散里 (Ch. 11); 'Suma' 須磨 (Ch. 12); 'Akashi' 明石 (Ch. 13); 'Melting Cloud' 薄雲 (Ch. 19) and others.

It must be noted that these elegant names, evoking an entire train of literary and artistic allusions, are very difficult to remember, being lined up one after another in the list. As a result of this, it seems that in the second half of the Edo period (at the end of the $18^{\text {th }}$ century), an unknown author created a rhythmically organized poem of seven and five syllables, which eventually became known as 'A Chain of Word-Names for 61 Types of Fragrances' (名香六十一種名寄文字鎖 Meikou rokujyuи ishhuи nayose moji kusari) ${ }^{35}$. Subsequently, it was included in publications for women's education. Among the earliest are editions such as 'Educational songs for chanting recitations for women' (女朗詠教訓歌 Jorouei kyoukun-uta, 1753) and 'Writings for women's reading' (女用続 文章 Joyou yomi bunsho, 1787) and some others (Fig. 2).

Based on the classifications of 61 types of aromatic wood compiled at the beginning of the $16^{\text {th }}$ century, another system was finally formed by the end of the $17^{\text {th }}$ century by two luminaries of koudou art - Sanjonishi Sanetaka and Shino Soshin, - called 'Six Countries - Five Flavours' (六国 五味 rikkoku-gomi), which united the best agar wood incents from India and tropical Asia with various types of flavours: 甘 kan (sweet), 酸 san (sour), 辛 shin (spiced), 鹹 kan (salty), 苦 $k u$ (bitter). Considering the places where aromatic plants grow, six varieties of agar wood were identified by the names of six countries: 伽羅 kyara wood with a spiced flavour and pungent smell (the best kinds from India, Vietnam); 羅国 rakoku sweet wood (Siam, Myanmar); 真那伽 manaka wood without any pronounced smell (Malacca, Malaysia); 寸聞多羅 sumotara bitter-salty, slightly sweet wood (Sumatra); 真南蛮 manaban sour-bitter wood (Malabar region on the eastern coast of South India) and the 佐曾羅 sasora wood with a cold and salty flavour (India and Indonesia) [Voytishek, 2011. P. 189-190; Voytishek, 2019. P. 70-71].

In accordance with this system, the highest quality kyara wood contained all five kinds of smells, which is why it was often called 五味立 gomi-tatsu ('containing five flavours'). The famous 蘭奢 待 ranjatai wood from the Todaiji Temple was believed to be of this type (Fig. 3).

As for the classification of 61 types of fragrant agar wood, it was reconsidered in the Edo period. Based on the already existing classification and in accordance with the 'Six Countries - Five Flavours' system, first of all, 11 varieties of wood were distinguished (six types of 伽羅 kyara wood native to India, three types of 羅国 rakoku wood native to Siam (modern-day Thailand), two types of 真那伽 manaka wood native to Malacca). Among the 50 remaining agar wood types, 41 types were identified as 伽羅 kyara, six types as 羅国 rakoku, nine types as 真那蛮 manaban native to the east coast of India, and five types as 真那伽 manaka native to Malacca ${ }^{36}$.

\footnotetext{
${ }^{35}$ See the original text on the Baikundo company website based in Awaji island. URL: http://www.baikundo.co. jp/61_fine_incense/ (accessed 08.05.2020). For the list of aromas and poem, see: [Ota Kiyoshi, 2001. P. 96-98].

${ }^{36}$ About the classifications of fragrant wood. URL: https://www.kigusuri.com/kampo/asano/asano_21.html (accessed 05.07.2020).
} 


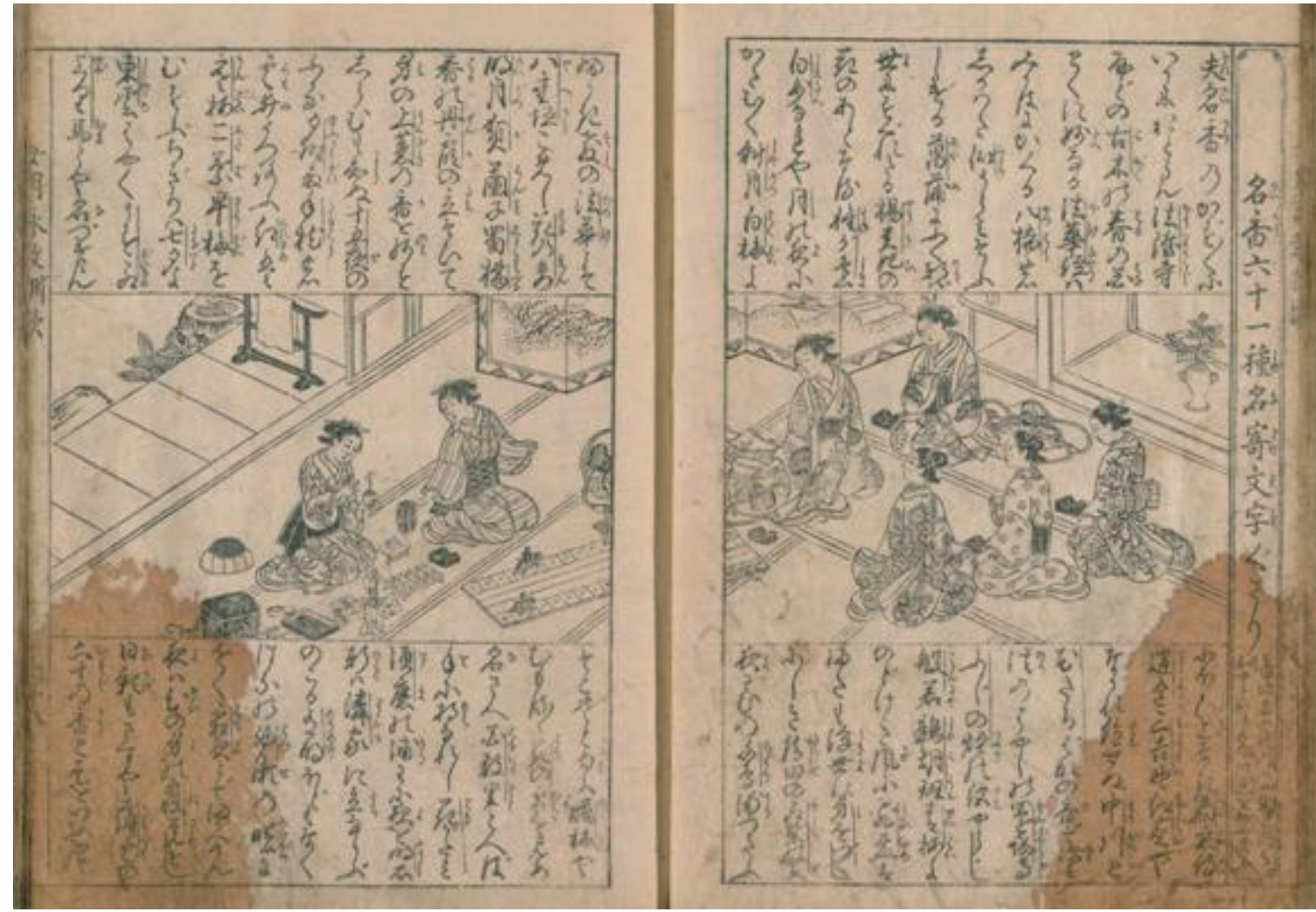

Fig. 2. Onna rouei kyoukunka [女朗詠教訓歌]. Educational songs for chanting recitations for women. Kyoto, Uemura Toemon, 1753. 1 note // Electron. Collection of the National Parliamentary Library. URL: https://dl.ndl.go.jp/ info:ndljp/pid/2533881 (accessed 07.07.2020)

Pис. 2. Онна ро:эй кё:кунка [女朗詠教訓歌]. Поучительные песни для декламации нараспев женщинами. Киото: Уэмура Тоэмон, 1753. 1 тетр. // Электрон. коллекция Национальной парламентской библиотеки. URL: https://dl.ndl.go.jp/info:ndljp/pid/2533881 (дата обращения 07.07.2020)

In addition, around the same time, two types began to be distinguished from the kyara wood the old (古伽羅 ko kyara) and new (新伽羅 shin kyara). As a result of these reconsidered types, a system of seven types of aromatic wood was gradually formed, which is still considered one of the most optimal and harmonious classifications. Currently, it is used by many experts in assessing the quality of aromatic wood [Peace and Harmony, 2011. p. 46-48; 112-113].

The above classification was founded on the principle of reliance on taste and olfactory receptors. Indeed, in order to determine an aroma type, fragrant wood is heated and the quality of the smell emanating from it is assessed ('sweet', 'sour', 'salty', 'bitter' or 'spiced'). According to the apt observation of Iwasaki Yoko of Doshisha University (Kyoto, Japan), labeling aromas with flavour and smell reveals another problem: smell is an extremely erratic sense. In addition, the human nose can become quickly accustomed to scents, which results in a short-lived ability to assess aromas. Consequently, the wisdom of medieval masters was contained within the ability to label scents with flavours, so that, due to such an encoding, specific aromas could be extracted from memory ${ }^{37}$.

\footnotetext{
${ }^{37}$ Iwasaki Yoko. Kaori to kigou genji-kou no zu-wo megutte [岩﨑陽子。香りと記号一源氏香之図をめぐって]. Incense and symbols: about the genji-kou no zu signs. Doshisha University, Human Security Research Centre, 2015. URL: http://perfumeartproject.com/wpcontent/uploads/2015/02/e0e34546e4dc307d6c75dd49e96cf306.pdf\#search= ' $\% \mathrm{E}$ 5\%BE\%8C\%Е6\%B0\%B4\%Е5\%B0\%BE\%Е9\%99\%A2+\%Е6\%BA\%90\%Е6\%B0\%8F\%Е9\%A6\%99\%Е3\%81\%AE\%Е5 $\% 9 \mathrm{~B} \% \mathrm{~B} 3$ (accessed 24.06.2020).
} 


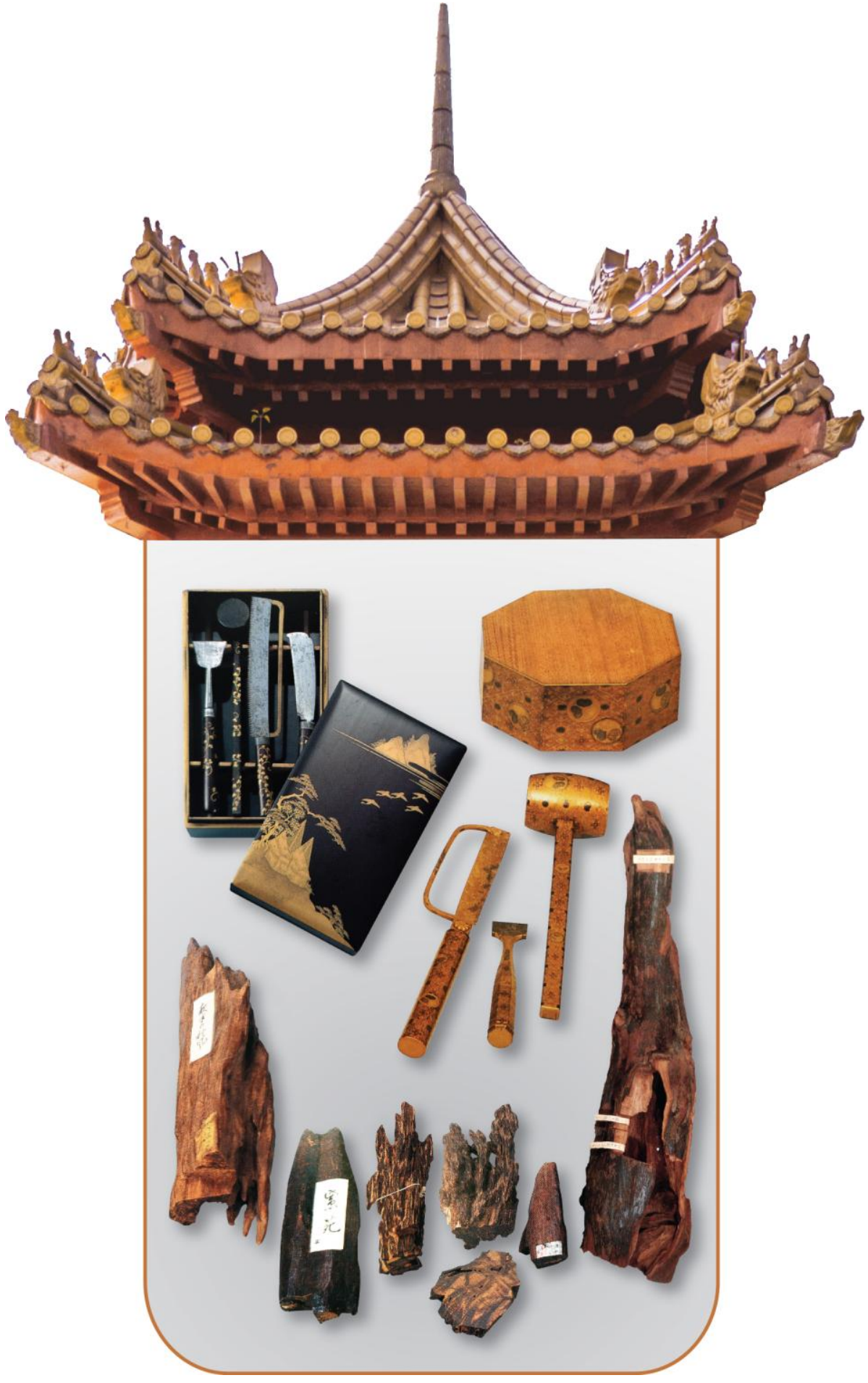

Fig. 3. Collage. From right to left: Wood of the famous agar tree 黄熟香 oujuku-kou (蘭奢待 ranjatai) from the Shoso-in National Treasury at Toudaiji Temple (Nara, Japan) (Shoso-in, 1994. p. 40); Aromatic wood 'Six Countries': rakoku, kyara, sumotara, manaka, manaban, sasora (length $42.5 \mathrm{~cm}$ ) (Koudougu, 2006. P. 80). On the top: Aromatic wood cutting tool sets (Koudougu, 2006. P. 149). (Collage by I. A. Axenov)

Рuc. 3. Коллаж. Справа налево: Знаменитая древесина агарового дерева 黄熟香 $o:$ зюку-ко: (蘭奢待 рандзятай) из национальной сокровищницы Сё:соин при храме То:дайдзи (Нара, Япония) (Сё:со:ин, 1994. С. 40); Ароматическая древесина «из шести стран»: ракоку, кяра, сумотара, манака, манабан, сасора (длиной 42,5 см) (Ко:до:гу, 2006. С. 80). Наверху: Наборы инструментов для разрезания ароматической древесины (Ко:до:гу, 2006. С. 149). (Коллаж - И. А. Аксёнов) 
Currently in Japan, aquilaria wood continues to be highly valued. In addition to its use in medicine, perfumery and cosmetology, agarwood has found its use in the art of 香道 koudou ('way of fragrance'), presenting the opportunity to enjoy incense in a refined atmosphere, appreciate its importance in religious ceremonies and the arts sphere. The Japanese are convinced that this art contributes to the purification of consciousness, awakens humanity and displays temperament. By 'listening to incense' (聞香 monkou) one can emphasize the beauty and uniqueness of each season [Morita Kiyoko, 2015. P. 13-15].

Ever since a piece of aromatic wood miraculously made its way into Japan, incense has become a part of everyday life of commoners, samurai, aristocrats, and wealthy merchants, eventually becoming a part of popular culture. Products made from aromatic wood entered the sphere of decorative applied arts long ago: it is used to carve out sculptures of characters from the Buddhist pantheon, figurines, vessels, jeweler boxes, fans, stands, and various game boards. A separate form of the Japanese art of incense was the manufacture of various and richly decorated tools for splitting and sawing bars of aromatic wood. The great importance of incense and various aromatic substances in the history of Japanese culture is underscored by the presence of a significant number of metaphors, idiomatic expressions and proverbs associated with the fragrant wood of aquilaria and sandalwood [Peace and Harmony, 2011. P. 113; Kan'yo kotowaza jiten, 1988; Kotowaza 15000 jiten, 1989; Nichiei hikaku kotowaza jiten, 1981].

\section{Conclusion}

Based on the analysis of Japanese written and artistic sources, as well as field research of the authors of the article, the main classifications of the aromatic wood species of the agar tree (aquilaria) which have played a large role in the culture of Japan for one and a half millennia, were considered. Some of these classifications are still used by authoritative experts when assessing the quality of wood and wood products.

The uniqueness of these classifications lies in their scientific significance, which is confirmed by the mass of historical and written sources, and also determined by their role in culture, literature, religious and everyday practices of the entire region. Attention is drawn to the undoubted discovery of medieval Japanese masters of methods of encoding one or another aroma of fragrant wood, associated not only with the specific characteristics of flavours and places of growth of aromatic trees, but also with the figurative-symbolic meaning of each name, the more notable ones of which are Buddhist and worldview concepts, philosophical categories, historical precedents, famous characters from the history of Japan and China, elements of the calendar year and festive rituals, natural phenomena, poetic and literary images, myths and legends.

Analysis of various types of aromatic wood invariably leads to the topic of formation and development of trade and economic ties in East, Southeast Asia and tropical regions of South Asia, to the study of the role of trade intermediaries from the Middle East and Central Asia (this is also indicated by archaeological finds from sunken ships, as well as burnt seals and inscriptions on pieces of wood in Sogdian, Persian and Pahlavi languages). Perhaps the discovery and study of new sources and artifacts in these languages in the future will make it possible to more accurately determine the routes of the merchant ships and fully appreciate the cultural finds. In addition, the study of the phenomenon of aromatic wood seems promising from the point of view of the existence of a specific category of 唐物 karamono goods ('items from China'), on the supply of which the habits and social status of the aristocracy, clergy and high military leaders largely depended.

The importance of aromatic culture in Japan, which has developed almost 1,500 years ago since the discovery of the aromatic wood bar off the coast of Awaji island is truly immense. As in many countries of East and Southeast Asia, it is not merely limited to medical, sanitary and hygienic functions, religious and cult practices, or everyday needs. However, it was only in Japan that the use of aromatic raw materials rose to become a true form of art. Having united with the ideological and worldview foundations of Buddhism and adopting the principles of aristocratic and later samurai 
ideology, the use of incense, enriched with various methods, techniques and accessories, over time transformed not only into traditional art, but also turned into a certain symbol of national culture, largely based on the awareness of the value of the present moment, the transience of life and the ephemerality of everything.

An unusually reverent and careful attitude to different types of aromatic substances, as well as to all the circumstances accompanying the history of their emergence, the peculiarities of use and evaluation, is one of the stable constants of traditional Japanese culture. There are many examples of this from ancient and modern Japanese history, one of which is the cultural phenomenon of fragrant wood, the boundaries of which to this day have never been fully defined to its fullest extent.

\section{References}

Ise monogatari ('Literature artifacts' series). Transl., comment. by N. I. Konrad. Moscow, Nauka, 1979, p. 287.

Ishigami Eiichi. Ho: ryu: ji garan engi narabini ryu: ki shizai cho: shoshahon-no denrai [石上英一。 法隆寺伽藍縁起并流記資財帳諸写本の伝来]. An introduction to the manuscript documents"Descriptions of the History and Property of the Horyuji Temple". Bulletin of the Institute of Historiography, 1976, no. 10, p. 1-10. (in Jap.)

Jinbo Hiroyuki. Koudou-no rekishi jiten [神保博行。香道の歴史事典]. In: Encyclopedia of the history of art of incense. Tokyo, Kashiwa-shobo, 2003, 454 p. (in Jap.)

Kan’yo kotowaza jiten [慣用ことわざ辞典]. Learning Dictionary of Proverbs. Tokyo, Shogakukan, 1988, 424 p. (in Jap.)

Kojiki - Records of Ancient Matters. Transl., comment. E. M. Pinus. St. Petersburg, SHAR, 1993, 320 p. (in Russ.)

Kojiki [古 事 記]. Records of Ancient Matters. Transl. to modern Jap. Fukunaga Takehiko. Tokyo, Kadokawa Shouten, 2014, 445 p. (in Jap.)

Kotowaza 15000 jiten [ことわざ 15000 辞典]. Dictionary of 15,000 proverbs. By Yamada Mitsuji. Osaka, Musashi shobo, 1989, 854 p. (in Jap.)

Koudougu [香道具]. Incense art accessories. By Arakawa Hirokazu. Kyoto, Tankosha, 2006, 255 p. (in Jap.)

Morita Kiyoko. The Book of Incense. Enjoying the traditional art of Japanese scents. New York, Kodansha, 2015, 134 p.

Nichiei hikaku kotowaza jiten [日英比較ことわざ辞典。監修山本忠尚]. Japanese-English Proverbs Comparative Dictionary. By Yamamoto Tadahisa. Tokyo, Sogensha, 1981, 394 p. (in Jap.)

Nihon shoki. Annaly Yaponii [Chronicles of Japan]. Transl. by L. M. Ermakova and A. N. Mesheryakov. St. Petersburg, Giperion, 1997, vol. 2, 427 p. (in Russ.)

Ota Kiyoshi. Kaori to chanoyu [太田清史。香と茶の湯]. Incense and tea ceremony. Kyoto, Tankousha, 2001, 190 p. (in Jap.)

Peace and Harmony [祥和。中國香港沉香珍藏展]. The Divine Spectra of China's Fragrant Harbour. A Collection of 108 Aloes of Sacred Scripture and Related Artifacts. Ed. by P. Kan. Hong Kong, 2011, 289 p. (in Chin. and Eng.)

Shoso-in [正倉院]. Shoso-in National Repository. Nara, Shoso-in jimusho kanshuu, 1994, 79 p. (in Jap.)

Voytishek E. E. Igrovye traditsii v dukhovnoi kul'ture stran Vostochnoi Azii (Kitai, Koreya, Yaponiya). Game tradition in the culture of East Asia countries (China, Korea, Japan). Novosibirsk, NSU Publ., 2011, 312 p., 44 p. with ill. (in Russ.) 
Voytishek E. E. The "Imperial Fragrance" of East Asian Culture: types, properties and features of the agarwood tree. Vestnik NSU. Series: History and Philology, 2019, vol. 18, no. 4: Oriental Studies, p. 61-74. (in Russ.)

\section{Список литературы}

Войтишек Е. Э. Игровые традиции в духовной культуре стран Восточной Азии (Китай, Япония, Корея). Новосибирск: изд-во Новосибирского госуниверситета, 2009. 296 с., 40 с. илл.

Войтишек Е. Э. «Царственный аромат» в культуре Восточной Азии: виды, свойства и особенности агаровых деревьев // Вестник НГУ. Серия: История, филология. 2019. Т. 18, № 4: Востоковедение. С. 61-74.

Дзимбо Хироюки. Ко:до:-но рэкиси дзитэн [神保博行。香道の歴史事典]. Словарь по истории искусства благовоний. Токио: Касива-сёбо, 2003. 454 с. (на яп. яз.)

Исигами Эйити. Хо:рю:дзи гаранэнги нарабини рю:ки сидзай тё: сёсяхон-но дэнрай [法隆寺 伽藍縁起并流記資財帳諸写本の伝来]. Введение в рукописные документы «Описания истории и имущества храма Хорюдзи» // Вестник Института историографии Токийского Университета. 1976. № 10. С. 1-10.

Исэ моногатари (серия «Литературные памятники») / Пер., примеч. Н. И. Конрада; изд. подгот. В. С. Санович. М.: Наука, 1979. 287 с.

Канъё котовадза дзитэн [慣用ことわざ辞典]. Учебный словарь пословиц. Токио: Сёгакукан, 1988. $424 \mathrm{c}$.

Кодзики - Записи о деяниях древности / Пер., коммент. Е. М. Пинус. СПб.: ШАР, 1993. 320 с.

Кодзики [古事記] Записи о деяниях древности / Пер. на совр. яп. яз. Фукунага Такэхико. Токио: Кадокава сётэн, 2014. 455 с.

Котовадза 15000 дзитэн [ことわざ 15000 辞典]. Словарь 15000 пословиц / Сост. Ямада Мицудзи. Осака: Мусаси сёбо, 1989. 854 с.

Ко:до:гу [香道具]. Художественная утварь искусства благовоний / Под ред. Аракава Хирокадзу. Киото: Танкося, 2006. 255 с. (на яп. яз.)

Morita Kiyoko. The Book of Incense. Enjoying the traditional art of Japanese scents. New York, Kodansha, 2015. 134 p.

Нитиэй хикаку котовадза дзитэн [日英比較ことわざ辞典。監修山本忠尚]. Японоанглийский сравнительный словарь пословиц / Под ред. Ямамото Тадахиса. Токио: Согэнся, 1981. 394 с.

Нихон Сёки. Анналы Японии / Пер. со старояп. Л. М. Ермаковой и А. Н. Мещерякова. СПб.: Гиперион, 1997. Т. 2. 427 с.

Ота Киёси. Каори то тя-но ю [太田清史。香と茶の湯]. Благовония и чайная церемония. Киото: Танко:ся, 2001. 190 с. (на яп. яз.)

Сё:со:ин [正倉院]. Национальное хранилище Сё:со:ин. Нара: Сё:со:ин дзимусё кансю:. 1994. 79 с. (на яп. яз.)

Peace and Harmony [祥和。中國香港沉香珍藏展]. The Divine Spectra of China's Fragrant Harbour. A Collection of 108 Aloes of Sacred Scripture and Related Artifacts / Ed. by P. Kan. Hong Kong, 2011. 289 р. (на кит. и англ. яз.) 


\section{Сведения об авторах}

Войтишек Елена Эдмундовна, доктор исторических наук, ведущий научный сотрудник, профессор, заведующая кафедрой востоковедения и руководитель направления «Востоковедение» Гуманитарного института НГУ (Новосибирск, Россия)

e.voitishek@g.nsu.ru

Речкалова Анастасия Александровна, ассистент кафедры востоковедения Гуманитарного института НГУ, младший научный сотрудник НОЦ «Наследие» ГИ НГУ (Новосибирск, Россия)

a.rechkalova@g.nsu.ru

\section{Information about the Authors}

Elena E. Voytishek, Doctor of History, Professor, Head of the Department of Oriental Studies, Institute for the Humanities, Novosibirsk State University (Novosibirsk, Russian Federation)

e.voitishek@g.nsu.ru

Anastasia A. Rechkalova, Assistant of the Department of Oriental Studies, Research Fellow of the Research and Educational Center "Heritage", Institute for the Humanities, Novosibirsk State University (Novosibirsk, Russian Federation)

a.rechkalova@g.nsu.ru 